\title{
SOSIALISASI SISTEM LAYANAN ASPIRASI DAN PENGADUAN ONLINE RAKYAT PADA MASYARAKAT DESA SEMANDING, KABUPATEN TUBAN
}

\section{(SOCIALIZATION OF PUBLIC ONLINE ASPIRATION SERVICES AND ONLINE COMPLAINTS IN SEMANDING TUBAN)}

\author{
Putu Aditya Ferdian Ariawantara ${ }^{1}$, Sulikah Asmorowati ${ }^{2}$, Erna Setijaningrum ${ }^{3}$ \\ ${ }^{1,2,3}$ Ilmu Administrasi Negara, Fakultas Ilmu Sosial dan Ilmu Politik, Universitas \\ Airlangga \\ e-mail: putu.aditya.ferdian.ariawantara@fisip.unair.ac.id
}

\begin{abstract}
Significant changes in the development of science and technology have had an impact on the implementation of public services. The government is required to increasingly provide transparent and accountable public services to the wider community. Along with the development of technology, the method of submitting complaints about public services has also changed, people can now submit their complaints through a system called LAPOR (People's Aspiration Service and Online Complaints to the Community). However, not all levels of society understand how to use the system, so the Administration Department, FISIP, Airlangga University initiated a community service program to socialize the LAPOR system in Semanding Village, Semanding District, Tuban Regency. The method used is a seminar with a structured two-way interaction pattern so that it is more focused in discussing issues or complaints that exist in the village to be submitted to the government.
\end{abstract}

Keywords: complaint management, public services, socialization

abstrak

Perubahan yang signifikan dalam perkembangan ilmu pengetahuan dan teknologi membawa dampak dalam implementasi pelayanan publik. Pemerintah dituntut untuk semakin menyediakan pelayanan publik yang transparan dan akuntabel kepada masyarakat luas. Seiring dengan perkembangan teknologi, metode penyampaian keluhan akan pelayanan publik juga ikut berubah, masyarakat saat ini bisa menyampaikan keluhannya melalui suatu sistem yang disebut LAPOR (Layanan Aspirasi dan Pengaduan Online Rakyat pada Masyarakat). Akan tetapi tidak semua lapisan masyarakat memahami bagaimana menggunakan sistem tersebut, sehingga Departemen Administrasi, FISIP, Universitas Airlangga menggagas kegiatan pengabdian masyarakat sosialisasi sistem LAPOR di Desa Semanding, Kecamatan Semanding, Kabupaten Tuban. Metode yang digunakan adalah dengan seminar dengan pola interaksi dua arah yang terstruktur sehingga lebih terfokus dalam membahas mengenai permasalahan atau keluhan yang ada di desa untuk disampaikan kepada pemerintah.

Kata Kunci: manajemen keluhan, pelayanan publik, sosialisasi

\section{PENDAHULUAN}

Era industrialisasi 4.0 membawa perubahan yang signifikan pada setiap sendi kehidupan masyarakat. Peranan internet, website, media sosial mewarnai aktivitas yang dilakukan oleh masyarakat baik di kota maupun di desa. Seiring perkembangan internet of think tersebut membawa konsekuensi akan transparansi dan akuntabilitas terhadap segala program maupun kebijakan yang diambil oleh pemerintah, diikuti dengan tuntutan akan pelayanan publik yang semakin berpihak kepada kepentingan masyarakat itu sendiri. 
Selain implementasi dari pelayanan publik yang disediakan pemerintah untuk masyarakat harus berpegang pada prinsip good governance, tuntutan juga muncul dalam segi evaluasi dalam bentuk pengaduan dari pelayanan publik itu sendiri yang muncul secara bottom up (dari masyarakat yang ditujukan kepada pemerintah penyelenggara pelayanan publik). Pelayanan publik yang berpedoman pada penyelenggaraan tata kelola pemerintahan yang baik harus memenuhi prinsip equity dan akuntabel di masyarakat dan menjalmin pengelolaan keuangan baik yang dibebankan kepada masyarakat atas jasa layanan tertentu (sesuai dengan peraturan perundang-undangan yang mendasarinya) maupun beban keuangan yang harus ditanggung oleh pemerintah akibat diimplementasikannya suatu pelayanan publik tertentu.

Pengaduan akan pelayanan publik yang dilakukan oleh masyarakat harus memiliki kemudahan dalam menyampaikan keluhannya. Pada era lampau pemerintah masih menggunakan akses hotline sebagai pengaduan pelayanan publik, kelemahannya beberapa nomer hotline tersebut masih ada yang membebankan biaya untuk pulsa dan dirasa sangat membingungkan karena masing-masing instansi pemerintah atau bahkan pada pelayanan publik tertentu memiliki nomor hotline yang berbeda-beda. Kemudian ada juga yang menggunakan faximile yang juga memiliki beban biaya dan tidak praktis untuk menggunakannya.

Dengan adanya perkembangan teknologi informasi dan komunikasi (TIK), semua pelayanan publik bisa dilakukan secara online tidak memandang batas ruang dan waktu (kecuali pelayanan administratif tertentu yang membutuhkan berkas hard copy harus disampaikan secara manual) dengan menggunakan TIK yang memudahkan dalam penyelenggaraan pelayanan. Perkembangan selanjutnya pengaduan akan pelayanan publik di era saat ini dilakukan dengan menggunakan website yang biayanya sangat terjangkau bahkan gratis apabila menggunakan akses wifi diruang publik, akan tetapi juga masih memiliki kelemahan yaitu setiap instansi atau program pelayanan publik memiliki website yang berbeda-beda. Kemudian pemerintah mengembangkan suatu sistem pengaduan yang disebut dengan LAPOR (Layanan Aspirasi dan Pengaduan Online Rakyat) yang lebih praktis dalam satu website. Sistem ini dapat mengelola seluruh keluhan masyarakat dan kemudian selajutnya disampaikan kepada instansi terkait yang berwenang untuk menanggapi laporan tersebut dengan outcome yaitu meningkatkan pelayanan publik pada kemudian hari sebagai akibat dari rekomendasi yang sudah diberikan oleh masyarakat tersebut.

Adapun pengaduan masyarakat yang terdapat dalam sistem LAPOR dibagi atas 41 (empat puluh satu) bidang yang dapat dijabarkan sebagai berikut: 1). Beras untuk keluarga sejahtera (Rastra); 2). Reformasi birokrasi dan tata kelola; 3). Pelayanan administrasi; 4). Permintaan informasi; 5). Pelaporan dan pelayanan administrasi; 6). Topic khusus (amnesti pajak); 7). Tidak aktif (apresiasi atau keluhan program); 8). Desa; 9). Situasi khusus; 10). Implementasi penyesuaian BBM termasuk bantuanbantuan untuk masyarakat; 11). Bantuan pangan; 12). Lembaga ombudsman DIY; 13). Kesehatan; 14). Ketenagakerjaan; 15). Keluhan layanan dan e-service; 16). Pembangunan desa, daerah tertinggal, terdepan, terluar, dan transmigrasi; 17). Pertambangan; 18). Restorasi gambut; 19). Jaga KPK; 20). Pariwisata; 21). Bantuan pangan non tunai; 22). Pelayanan obat; 23). Pelayanan kesehatan; 24). Migas; 25). Pertanian; 26). Perhutanan social; 27). Kartu keluarga sejahtera; 28). BPJS kesehatan; 
29). Lingkungan hidup dan penanggulangan bencana; 30). Kemaritiman; 31). Iuran; 32). BPJS ketenagakerjaan; 33). Bidang politik, hukum, dan keamanan; 34). Bidang perekonomian; 35). Reforma agrarian; 36). Energy dan sumber daya alam; 37). Pemilu; 38). Listrik; 39). Bidang kesejahteraan rakyat; 40). Pendidikan; dan 41). Infrastruktur.

Seiring dengan adanya pengaduan yang dapat disampaikan oleh masyarakat dalam sistem LAPOR, tidak semua masyarakat memahami atau bahkan belum mengetahui bahwa setiap pelayanan publik yang disediakan oleh pemerintah apabila terjadi kesalahan atau mal-administrasi keluhan tersebut dapat disampaikan secara online melalui www.lapor.go.id. Tidak jarang bahkan masyarakat yang sudah mengetahui pengaduan tersebut tidak mengerti lembaga pemerintah mana yang menerima dan menindaklanjuti pengaduannya. Seperti yang terjadi pada masyarakat di Desa Semanding, Kecamatan Semanding, Kabupaten Tuban. Selama ini mereka hanya melaporkan pengaduan pelayanan melalui RT, RW, aparatur desa, Bayan, maupun Kepala Desa. Mengingat keterbatasan jumlah yang dimiliki aparatur desa hal ini dinilai tidak efisien dan efektif mengingat keluhan akan pelayanan publik sangat beragam. Berdasarkan atas masalah tersebut Departemen Administrasi, Fakultas Ilmu Sosial dan Ilmu Politik Universitas Airlangga mengadakan kegiatan pengabdian masyarakat dengan tema Sosialisasi Sistem Layanan Aspirasi dan Pengadian Online Rakyat pada Masyarakat Desa Semanding, Kabupaten Tuban.

\section{METODE PENGABDIAN MASYARAKAT}

Metode dalam melaksanakan pengabdian kepada masyarakat yang dilakukan oleh Departemen Administrasi, FISIP, Universitas Airlangga di Desa Semanding, Kecamatan Semanding, Kabupaten Tuban adalah dirancang sebagai berikut: 1). Analisa situasi masyarakat; 2). Mengidentifikasikan masalah yang terjadi atau dihadapi oleh masyarakat; 3). Menentukan tujuan atas tindakan aksi pengabdian kepada masyarakat; 4). Menentukan obyek dari pengabdian masyarakat; dan 5). Melaksanakan pengabdian masyarakat.

Analisa situasi masyarakat. Jumlah total penduduk di Desa Semanding adalah sebanyak 3500 orang terdiri atas 1.686 orang penduduk laki-laki dan 1.814 jumlah penduduk perempuan serta 1.072 kepala keluarga (data BPS Kecamatan Semanding dalam Angka 2018). Desa Semanding merupakan ibukota dari Kecamatan Semanding, dan sebagian besar penduduknya masih mengandalkan lahan pertanian sebagai mata pencaharian. Dilain itu penduduk juga bekerja sebagai PNS dan banyak juga yang bergerak disektor swasta dengan membuka usaha toko, depot, warung kopi, jasa perbaikan, dan lain sebagainya.

Identifikasi masalah. Masalah yang terjadi secara riil di masyarakat dalam kaitannya dengan kegiatan ini adalah masyarakat tidak mengetahui jalur untuk melakukan pengaduan terhadap pelayanan publik yang diberikan oleh pemerintah. Sehingga sebagai civitas akademika Universitas Airlangga dengan konsentrasi Ilmu Administrasi Negara merasa berkewajiban untuk memberikan sosialisasi mengenai sistem LAPOR untuk memudahkan masyarakat memberikan pengaduan pelayanan publik dengan tujuan yang konstruktif dan mengoptimalisasikan pelayanan publik yang disediakan oleh pemerintah di kemudian hari. Dari ketidaktahuan masyarakat tersebut dibutuhkan sosialisasi yang terarah mengenai sistem LAPOR. Tim pengabdian masyarakat dari 
Departemen Administrasi mengidentifikasikan masalah ini dengan melakukan survey pendahuluan sebelum pelaksanaan pengabdian masyarakat. Dari survey pendahuluan tersebut diketahui bahwa masyarakat di Desa Semanding sebagian besar belum memahami mengenai sistem LAPOR, kemudian tim menganalisis bahwa kemungkinan masalah yang akan timbul adalah dibidang: 1). Beras untuk keluarga sejahtera (Rastra); 2). Reformasi birokrasi dan tata kelola; 3). Pelayanan administrasi; 4). Pelaporan dan pelayanan administrasi; 5). Desa; 6). Bantuan pangan; 7). Kesehatan; 8). Ketenagakerjaan; 9). Pembangunan desa, daerah tertinggal, terdepan, terluar, dan transmigrasi; 10). Bantuan pangan non tunai; 11). Pertanian; dan 12). Bidang kesejahteraan rakyat.

Menentukan tujuan atas tindakan aksi pengabdian kepada masyarakat. Kegiatan pengabdian masyarakat Departemen Administrasi berjudul Pengelolaan Pengaduan Masyarakat Melalui Aplikasi Layanan Aspirasi Dan Pengaduan Online Rakyat (LAPOR) bertujuan untuk: 1). Membantu pemerintah dalam menyosialisasikan program pemerintah dan produk hukum yang melindunginya; 2). Meningkatkan pengetahuan dan pemahaman perangkat daerah akan pentingnya menerapkan prinsip keterbukaan pemerintah; 3). Meningkatkan kesadaran masyarakat akan aplikasi pengaduan pelayanan publik; 4). Melatih masyarakat agar secara mandiri mampu untuk melaporkan pengaduan pelayanan publik melalui aplikasi LAPOR; dan 5). Membantu terciptanya keterbukaan pemerintah dan frekuensi dialog antara aparat sipil negara dengan masyarakat.

Menentukan obyek dari pengabdian masyarakat. Obyek dari kegiatan pengabdian masyarakat ini adalah perangkat Desa Semanding, tokoh masyarakat, tokoh pemuda, ibu-ibu PAUD, dan ibu-ibu PKK. Harapannya adalah dengan diberikannya sosialisasi mengenai LAPOR kepada tokoh masyarakat, mereka bisa melakukan 'getok tular' kepada anggota masyarakat lain yang ada di wilayah Desa Semanding, Kecamatan Semanding, Kabupaten Tuban atau dengan cakupan yang lebih luas lagi apabila mereka memiliki kerabat diluar daerah obyek sasaran.

Pelaksanaan pengabdian kepada masyarakat. Pelaksanaan kegiatan ini dilakukan pada tanggal 28-29 November 2018 berlokasi di pendopo Desa Semanding. Pelaksana kegiatan pengabdian masyarakat ini adalah seluruh dosen pada Departemen Administrasi FISIP Universitas Airlangga. Pada pelaksanaan tersebut indikator keberhasilannya adalah aparatur perangkat desa dapat secara profesional menangani pengaduhan pelayanan publik serta masyarakat dapat secara aktif memanfaatkan aplikasi pengaduan pelayanan publik.

\section{HASIL DAN PEMBAHASAN}

Manajemen komplain secara umum dikemukakan oleh Tjiptono (2009) adalah merupakan suatu sistem yang digunakan untuk memonitor sikap dan kepuasan para pelanggan, penyalur, dan partisipan lain dalam sistem pemasaran sehingga ketika terjadi permasalahan, manajemen dapat mengambil langkah yang lebih cepat untuk menyelesaikannya. Definisi tersebut ternyata tidak hanya berlaku untuk suatu sistem komersiil saja, tetapi juga bisa diberlakukan pada pelayanan publik yang disediakan oleh pemerintah. Dalam paradigma good governance, partisipasi masyarakat sebagai warga negara memiliki peranan penting dalam mendukung sistem maupun program 
yang disediakan oleh pemerintah. Tidak hanya sebagai obyek saja, tetapi masyarakat juga dilibatkan atau berpartisipasi aktif dalam agenda yang sudah disiapkan oleh pemerintah. Oleh sebab itu pada tahun 2009 muncul pendekatan baru dalam administrasi publik yaitu sound governance.

Manajemen komplain atau manajemen keluhan merupakan penggabungan dari dua kata yaitu manajemen dan komplain atau keluhan. Manajemen adalah bagaimana cara menggerakkan sekelompok orang untuk mencapai tujuan tertentu dan mencakup tugastugas perencanaan, pengorganisasian, pelaksanaan, dan mekanisme kontrol atau evaluasi. Jadi manajemen adalah bagaimana mencapai tujuan secara bersama-sama (Soedjais et al, 2002). Dalam bidang pemerintahan dalam mencapai tujuan ada banyak komponen, satuan kerja, sistem, peraturan perundang-undangan atau hal-hal terkait lainnya secara bersama-sama untuk mencapai tujuan yang tertuang dalam visi, misi pemerintah itu sendiri. Sedangkan komplain atau keluhan adalah suatu ungkapan yang keluar karena perasaan menderita (karena menderita sesuatu yang berat, kesakitan dan sebagainya (Alwi, 2002:156). Keluhan ini dapat diungkapkan secara verbal maupun tertulis. Komplain atau keluhan masyarakat merupakan bentuk penerapan dari pengawasan masyarakat atau respon atas ketidakpuasan terhadap pelayanan administratif, pelayanan barang, dan/atau pelayanan jasa yang diberikan oleh penyedia pelayanan. Sehingga komplain atau keluhan sangat penting untuk dikelola sebagai suatu respon yang konstruktif bagi penyedia pelayanan barang maupun jasa yang dimaksudkan.

Untuk mempermudah pengaduan masyarakat atas pelayanan publik yang disediakan oleh pemerintah, maka dibuatlah suatu sistem LAPOR yang merupakan akronim dari Layanan Aspirasi dan Pengaduan Online Rakyat. Sebagai salah satu inisiatif yang saat ini cukup berkembang di Indonesia adalah LAPOR adalah sarana aspirasi dan pengaduan berbasis elektronik dan daring yang dijalankan dengan prinsip mudah, terpadu, dan tuntas. LAPOR dikelola dan dikembangkan oleh Kementerian Pendayagunaan Aparatur Negara dan Reformasi Birokrasi bersama Kementerian Dalam Negeri, Kantor Staf Presiden, dan Ombudsman Republik Indonesia sebagai saluran partisipasi masyarakat untuk pengawasan pembangunan dan pelayanan publik di Indonesia. Hingga hari ini, LAPOR telah terintegrasi dengan lebih dari 500 Kementerian, Lembaga, Pemerintah Daerah, Badan Usaha Negara baik di dalam maupun di luar negeri. Artinya, keseriusan pemerintah cukup dilihat dari upaya pengintegrasian yang sudah dilakukan selama lima tahun beroperasinya inisiatif ini.

Sejak 2013, LAPOR telah ditetapkan sebagai Sistem Pengelolaan Pengaduan Pelayanan Publik Nasional (SP4N). Keberadaan LAPOR juga dapat dikatakan sebagai bentuk nyata pelaksanaan amanat Undang-Undang Nomor 25 Tahun 2009 tentang Pelayanan Publik dan Peraturan Presiden Nomor 76 Tahun 2013 tentang Pengelolaan Pengaduan Pelayanan Publik. Adanya instrumen-instrumen hukum tersebut menggambarkan LAPOR haruslah diimplementasikan tidak hanya sampai pada Lembaga Tinggi Negara saja, melainkan juga dikerjakan dan dikelola sebaik-baiknya oleh Aparatur Sipil Negara di level apapun. Mengingat peran pentingnya LAPOR, maka sangat penting bagi aparatur negara untuk benar-benar menguasai pengetahuan juga kemampuan operasional dalam menangani keluhan masyarakat. 
Aplikasi LAPOR didasarkan dan dilindungi oleh beberapa produk hukum diantaranya adalah sebagai berikut: 1). Undang-Undang Nomor 12 Tahun 2008 tentang Pemerintah Daerah; 2). Undang-Undang Nomor 12 Tahun 2008 tentang Pemerintah Daerah; 3). Undang-Undang Nomor 25 Tahun 2009 tentang Pelayanan Publik; 4). Peraturan Pemerintah Nomor 96 Tahun 2012 tentang Pelaksanaan Undang-Undang Nomor 25 tahun 2009 tentang Pelayanan Publik; dan 5). Peraturan Presiden Nomor 76 Tahun 2013 tentang Pengelolaan Pengaduan Pelayanan Publik.

Sebagai salah satu departemen yang berfokus pada kajian kebijakan, pembangunan, dan pelayanan publik, Departemen Administrasi Universitas Airlangga sangat mendukung terselenggaranya implementasi LAPOR sebagai upaya realisasi pemerintahan terbuka dan peningkatan kualitas pelayanan publik. Kami menilai, dosen dan akademisi juga mempunyai peran yang signifikan dalam menentukan keberhasilan program ini. Adapun, Departemen Administrasi dapat membantu penyuluhan dan penguatan pemahaman para Aparatur Sipil Negara melaui seminar dan diskusi publik. Selain itu, karena inisiatif LAPOR yang bersumber pada umpan balik masyarakat, sangat penting pula bagi pemangku kepentingan untuk menyosialisasikan tata cara penggunaan pada fitur-fitur LAPOR dengan tujuan membangkitkan dan meningkatkan partisipasi masyarakat.

Secara umum, masyarakat dapat menyampaikan aspirasi dan pengaduan via LAPOR dengan beberapa cara sebagai berikut: 1). Situs www.lapor.go.id; 2). SMS ke 1708 (tarif normal); 3). Aplikasi seluler LAPOR; 4). Twitter @LAPOR1708 dengan menyertakan tagar \#lapor; 5). Saluran pengaduan lain yang telah diintegrasikan.

Laporan akan diverifikasi dan diteruskan kepada instansi yang berwenang untuk dapat ditindaklanjuti. Masyarakat juga dapat mengawal penanganan setiap laporan secara transparan dan akuntabel melalui berbagai fitur yang tersedia, termasuk fitur-fitur untuk mendukung keamanan dan kenyamanan pelapor. Sebagai sistem pengaduan yang terpadu dan berjenjang, LAPOR! telah terhubung dengan berbagai instansi pemerintah, dengan ketentan sebagai berikut: (Data: Mei 2018) 1). 107 Kementerian/Lembaga; 2). 551 Pemerintah Daerah; 3). 117 BUMN (Badan Usaha Milik Negara); 4). 1.816 Instansi Lainnya.

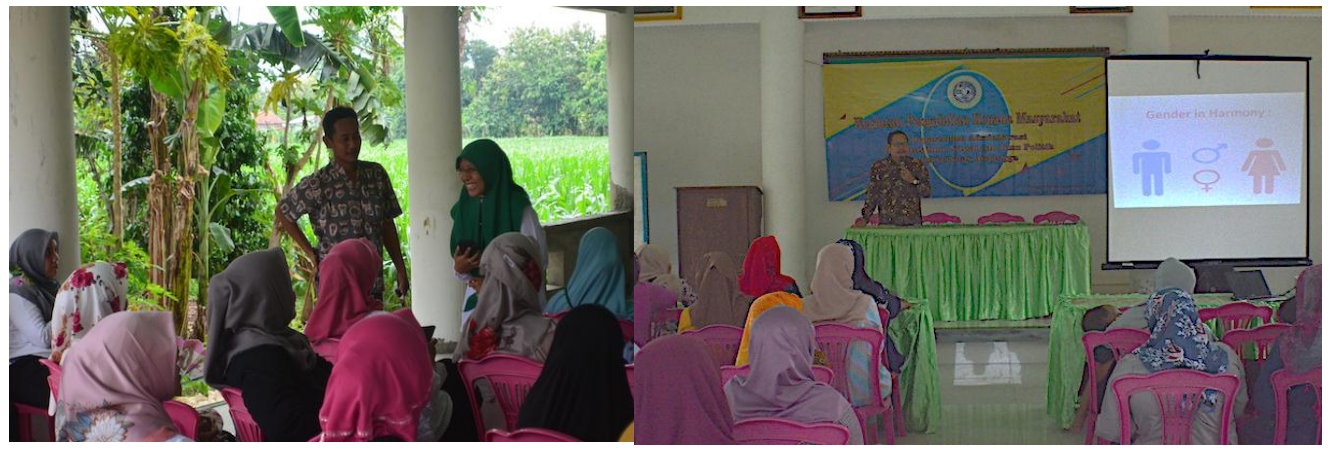

Gambar 1. Interaksi Pre-Test Antara Dosen Departemen Administrasi Dengan Masyarakat 
Kegiatan pengabdian masyarakat dilakukan dengan mengumpulkan warga sasaran di pendopo Desa Semanding, Kecamatan Semanding, Kabupaten Tuban. Pertama sebelum menginjak pada bagaimana cara menggunakan LAPOR, tim pengabdian masyarakat Departemen Administrasi FISIP Unair memberikan pre-test akan tetapi bukan dalam bentuk tertulis namun interaksi tanya jawab antara peserta dan narasumber. Dari hasil interaksi tersebut diketahui bahwa sebagian besar masyarakat obyek sasaran belum banyak mengetahui mengenai sistem LAPOR itu sendiri. Setelah itu baru narasumber memberikan materi mengenai pentingnya manajemen komplain terhadap suatu layanan publik yang disediakan pemerintah, hingga definisi dari LAPOR dan mengapa pemerintah membuat sistem tersebut. Kemudian narasumber menjelaskan mengenai mekanisme alur kerja sistem LAPOR.

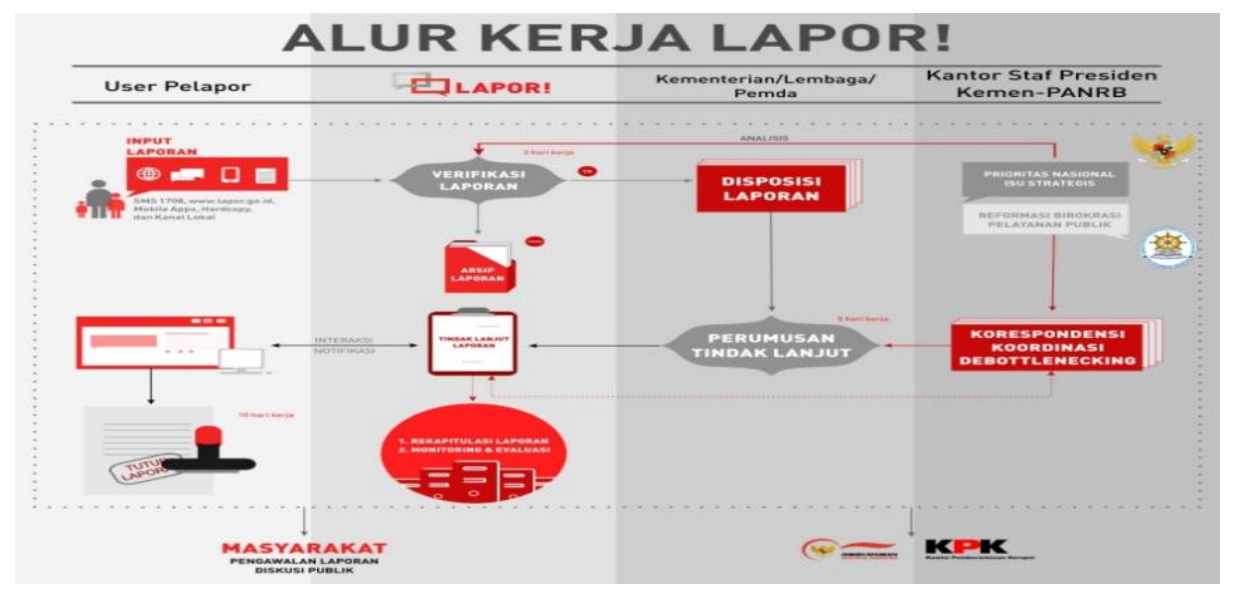

Gambar 2. Alur Kerja LAPOR

Dari gambar 2 diatas dapat diuraikan penjelasan alur kerja penggunaan aplikasi LAPOR adalah sebagai berikut, pertama, masyarakat menyampaikan laporan melalui salah satu dari kanal berikut: a). Situs www.lapor.go.id; b). SMS ke 1708 (tarif normal); c). Mobile apps LAPOR! (Android); d). Twitter @LAPOR1708 dengan menyertakan tagar \#lapor; dan e). Saluran pengaduan lain yang telah diintegrasikan.

Kedua, verifikasi laporan. Verifikasi laporan adalah proses pemeriksaan substansi laporan oleh administrator dalam waktu paling lambat 3 (tiga) hari kerja. Verifikasi dilakukan untuk memastikan setiap laporan disampaikan secara jelas, lengkap, dan kronologis serta disertai data dukung yang memadai (jika ada). Verifikasi sangat penting agar laporan masyarakat dapat diteruskan kepada instansi yang tepat dan mempermudah proses tindak lanjut laporan. Pada saat verifikasi laporan, administrator akan memandu pelapor jika terdapat informasi dan data yang perlu dilengkapi. Masyarakat tidak perlu ragu terkait kewenangan instansi yang dituju karena administrator akan memandu prosesnya. Laporan yang jelas, lengkap, dan kronologis akan diteruskan kepada instansi yang berwenang untuk dapat ditindaklanjuti.

Ketiga, tindak lanjut laporan. Instansi diwajibkan menindaklanjuti setiap aspirasi dan pengaduan secara cepat dan tepat sesuai tugas, fungsi, dan kewenangannya. Instansi akan melakukan analisis terhadap substansi laporan, berkoordinasi dengan pihak-pihak terkait, menindaklanjuti di lapangan, serta memberikan jawaban resmi melalui aplikasi LAPOR. 
Jangka waktu untuk menindaklanjuti laporan bergantung pada jenis dan bobot laporan, sebagai berikut: 1). Ringan: jenis laporan mengenai apresiasi, aspirasi, dan permintaan informasi. Contohnya, pertanyaan mengenai prosedur, permintaan informasi publik, dsb. Standar waktu tindak lanjut paling lambat 5 (lima) hari kerja; 2). Sedang: jenis laporan mengenai pengaduan yang tidak berkadar pengawasan atau pengaduan yang penyelesaiannya dapat dilakukan oleh satu instansi. Contohnya, keluhan mengenai standar pelayanan. Standar waktu tindak lanjut paling lambat 14 (empat belas) hari kerja; 3). Berat: jenis laporan mengenai pengaduan yang berkadar pengawasan, adanya indikasi penyalahgunaan wewenang, pengaduan yang penyelesaiannya bersifat lintassektoral, atau pengaduan terkait infrastruktur besar. Contohnya, pengaduan terkait infrastruktur, pengaduan mengenai korupsi, kolusi, dan nepotisme, dsb. Standar waktu tindak lanjut paling lambat 30 (tiga) puluh hari kerja.

Keempat, penutupan laporan. Penutupan laporan dilakukan terhadap laporan yang telah selesai ditindaklanjut. Penutupan laporan didasarkan pada hal-hal berikut ini: 1). Pelapor memberikan pernyataan kepuasan atas tindak lanjut yang diberikan (Penutupan dilakukan oleh administrator); 2). Pelapor memberikan pernyataan kepuasan atas tindak lanjut yang diberikan dan menutup sendiri laporannya (Penutupan dilakukan oleh pelapor); 3). Tidak adanya respons, tanggapan, atau sanggahan lebih lanjut dalam waktu 10 (sepuluh) hari kerja terhadap tindak lanjut yang diberikan instansi (Penutupan dilakukan secara otomatis oleh sistem); 4). Adanya debat kusir terkait tindak lanjut laporan. Debat kusir yang dimaksud yaitu apabila pelapor memberikan sanggahan secara berkepanjangan namun tidak menyertakan alasan yang logis atau informasi dan data terkait sanggahannya (Penutupan dilakukan oleh administrator).

LAPOR memiliki fitur-fitur pendukung yang disediakan bagi pengguna, antara lain: 1). Tracking ID, tracking ID merupakan nomor tiket yang dapat digunakan untuk memantau status penanganan setiap laporan; 2). Notifikasi, notifikasi merupakan pemberitahuan resmi mengenai status laporan. Pelapor akan menerima notifikasi ketika laporan telah diteruskan, ketika laporan telah ditindaklanjuti, ketika laporan telah tertutup, dan bahkan ketika laporan tidak dapat diproses lebih lanjut; 3). Kolom Tindak Lanjut Laporan, kolom tindak lanjut laporan adalah ruang interaksi dua arah antara pelapor dan instansi terlapor. Pada saat laporan ditindaklanjuti, pelapor berkesempatan untuk memberikan umpan balik terhadap tindak lanjut tersebut sehingga kualitas tindak lanjut dapat dikawal oleh semua pihak. Dengan demikian, diharapkan muncul solusi terbaik yang substansial untuk setiap permasalahan dan kebutuhan masyarakat; 4). Indikator Warna (Merah, Kuning, Hijau), indikator warna disediakan untuk memudahkan masyarakat dalam mengetahui progres penanganan setiap laporan. Merah artinya laporan belum ditangani, Kuning artinya laporan sedang dalam proses penanganan, dan Hijau artinya laporan telah selesai ditangani dan telah ditutup; 5). Statistik, disediakan secara terbuka dalam bentuk rekapitulasi agar masyarakat dapat mengetahui dan mengawasi kinerja pengelolaan pengaduan setiap instansi. Statistik dalam format yang lebih rinci dapat disediakan dengan menghubungi pengelola; 6). Anonim dan Rahasia, laporan yang telah diteruskan kepada instansi bersifat terbuka. Namun demikian, pelapor maupun administrator dapat menggunakan fitur anonim dan/atau rahasia agar identitas pelapor dirahasiakan dan/atau agar laporan tidak terpublikasi. Fitur ini dimaksudkan untuk menjaga keamanan dan kenyamanan pelapor, khususnya terkait substansi laporan yang sensitif. 
Kegiatan pengabdian kepada masyarakat yang dilaksanakan oleh Departemen Adiministrasi FISIP Unair di Desa Semanding, Kecamatan Semanding, Kabupaten Tuban memiliki obyek sasaran yang dibagi menjadi dua kelompok besar, yaitu ibu-ibu PKK sebagai kelompok pertama dan aparatur desa, tokoh masyarakat, ketua RT, ketua RW, dan tokoh pemuda sebagai kelompok kedua. Sosialisasi mengenai sistem LAPOR yang dilaksanakan bagi kelompok pertama dilaksanakan dengan narasumber dosendosen perempuan dengan tujuan lebih mengakrabkan antara kelompok sasaran dan narasumber. Sedangkan bagi kelompok kedua dilakukan dengan narasumber dosen pria, karena selain kelompok kedua semuanya adalah laki-laki kegiatan pada hari kedua juga dilaksanakan pada malam hari.

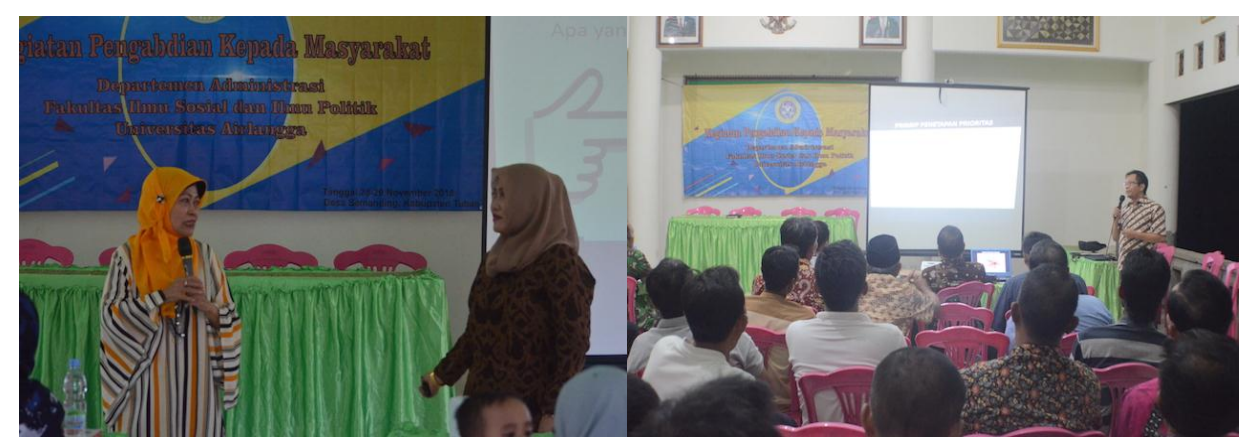

Gambar 3. Sosialisasi LAPOR pada Dua Kelompok Masyarakat

Pelaksanaan sosialisasi sistem LAPOR kepada masyarakat di Desa Semanding, Kecamatan Semanding, Kabupaten Tuban dilakukan dengan menunjukkan langkah demi langkah penggunaan aplikasi ini. Aplikasi LAPOR sangat mudah digunakan dalam menyampaikan keluhan di masyarakat mengenai pelayanan publik yang dari pemerintah. Sebelum menuliskan laporan mengenai keluhan akan pelayanan publik, masyarakat bersangkutan harus mengisi data untuk log in (gambar 3) dalam situs www.lapor.go.id. Setelah mengisi data lengkap maka masyarakat bersangkutan bisa memilih menu jenis laporan apa yang disampaikan dan mengisi detail laporan beserta data-data yang diperlukan untuk menunjang keluhan tersebut (gambar 4).

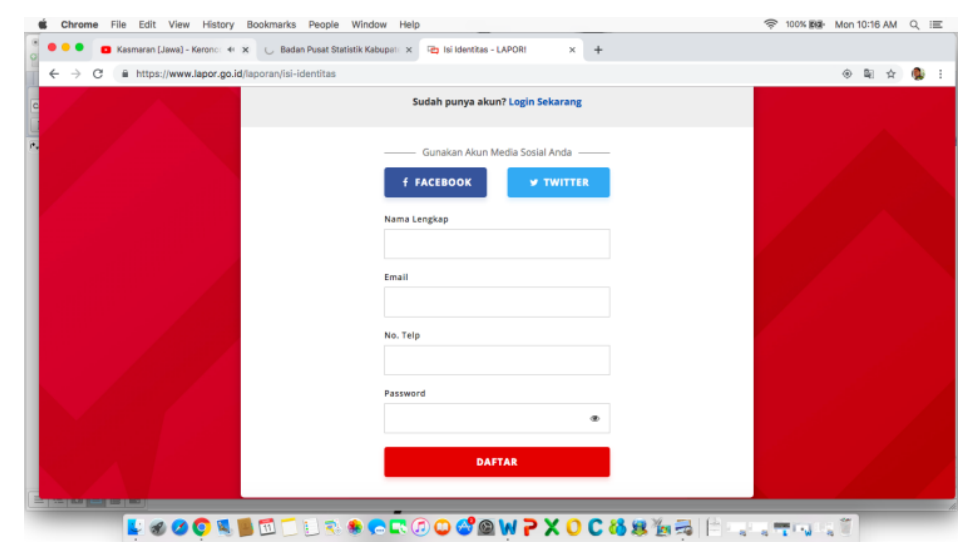

Gambar 4. Log In Aplikasi LAPOR 


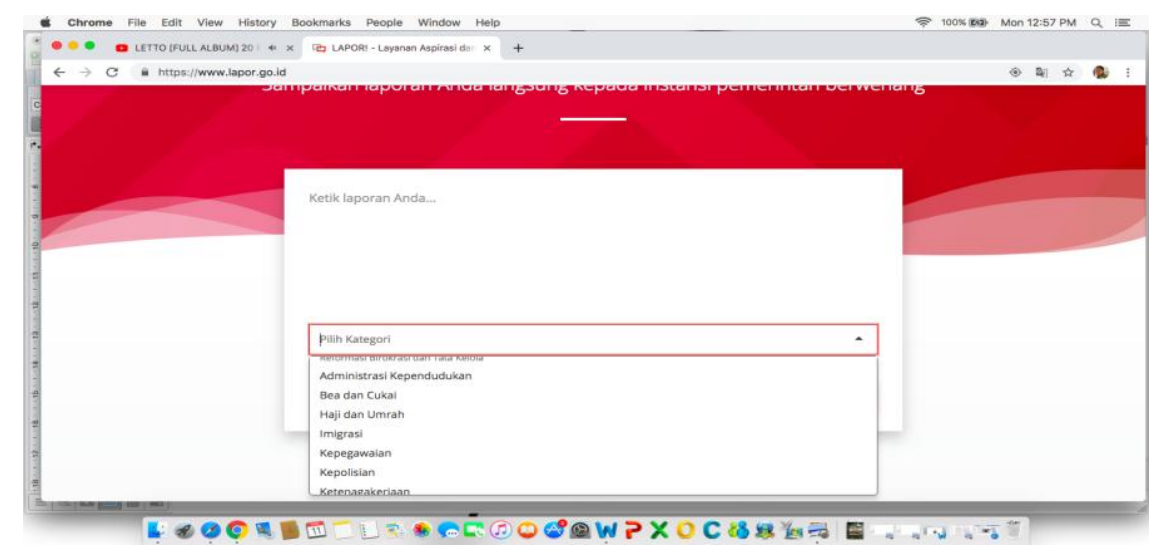

Gambar 5. Menu Keluhan dalam Aplikasi LAPOR

Keluhan masyarakat dalam aplikasi LAPOR akan mendapatkan tanggapan dari instansi pemerintah yang terkait. Memang untuk proses tanggapan hingga penyelesaian membutuhkan waktu yang bervariatif, mengingat setiap hari keluhan yang masuk dalam aplikasi LAPOR bisa berjumlah hingga ratusan ribu. Beberapa keluhan yang sudah mendapatkan tanggapan dapat dilihat pada gambar 5 dibawah ini. Pada gambar tersebut dapat dilihat bahwa keluhan masyarakat bisa ditampilkan pada website sehingga tidak hanya instansi yang bersangkutan saja yang dapat membaca, akan tetapi masyarakat luas yang kebetulan mengakses website tersebut. Keluhan yang disampaikan masyarakat juga mendapatkan tanggapan atau yang sudah selesai dapat dilihat pada kolom paling kanan yaitu 'Kisah Sukses'.

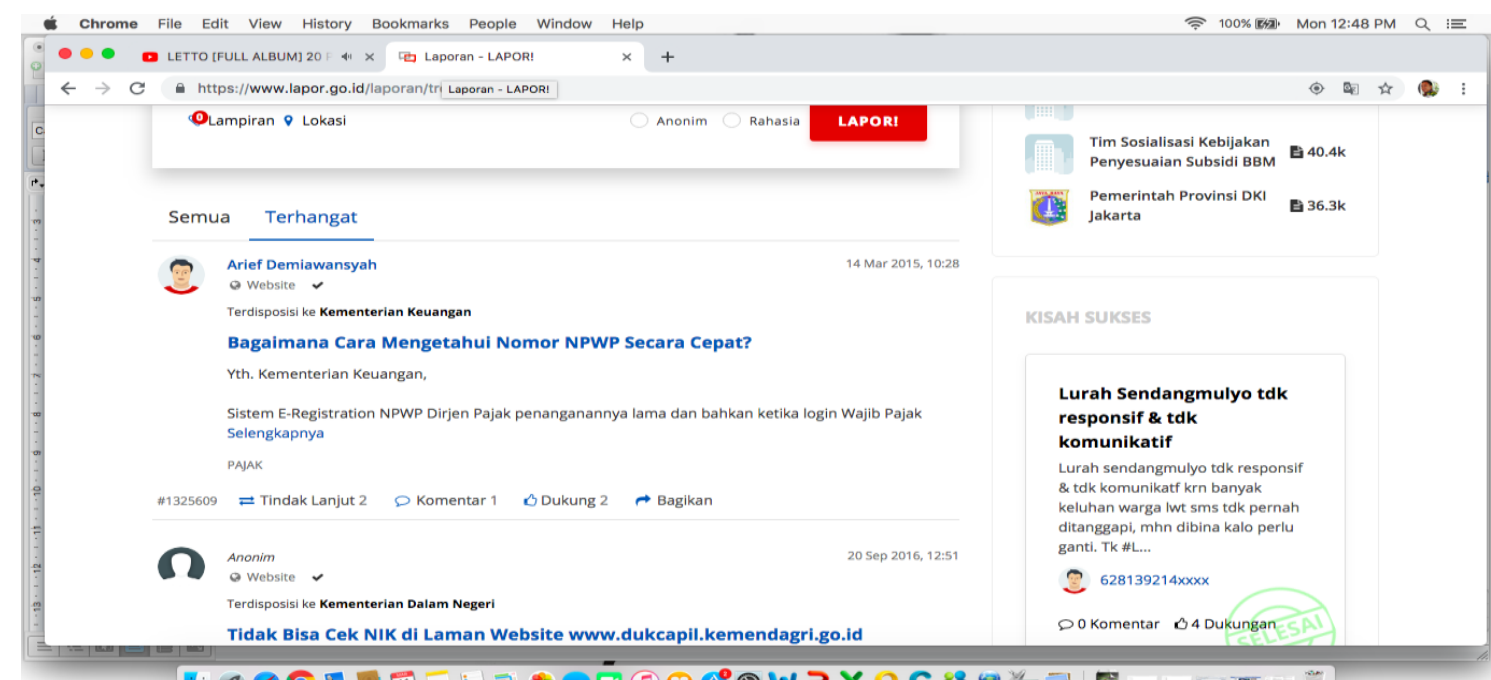

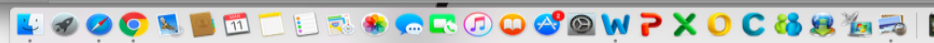

Gambar 6. Record Keluhan Masyarakat dan Kisah Sukses Keluhan yang Sudah ditanggapi

\section{PENUTUP}

\section{Simpulan}

Sistem LAPOR ternyata belum banyak dikenal oleh masyarakat khususnya di wilayah pedesaan. Selama ini keluhan yang ada di masyarakat hanya disampaikan melalui aparatur desa yang jumlahnya terbatas, ditambah lagi tidak ada mekanisme kontrol terhadap posisi keluhan tersebut sampai diposisi mana. Sehingga keluhan masyarakat desa akan pelayanan publik yang disediakan oleh pemerintah tidak dapat tersampaikan dengan baik. Dari keluhan masyarakat di wilayah pedesaan yang belum banyak 
disampaikan sebagai suatu mekanisme kontrol yang konstruktif terkait kebijakan, program, dan pelayanan publik yang diberikan oleh instansi pemerintah, menyebabkan terjadinya lack of control, lack of public partisipation, yang berujung pada maladministrasi maupun program yang tidak tepat sasaran. Sehingga dengan adanya sosialisasi mengenai sistem LAPOR pada Desa Semanding, Kecamatan Semanding, Kabupaten Tuban masyarakat dan pemerintah memiliki suatu saluran komunikasi dua arah dan mendorong akan transparansi dan akuntabilitas publik.

\section{Saran}

Tim pengabdian masyarakat Departemen Administrasi FISIP Universitas Airlangga memiliki beberapa saran mengenai kegiatan ini dimasa yang akan datang. Pertama, aparatur Desa Semanding harus ikut berpartisipasi aktif dalam mempelopori masyarakat desa untuk mengungkapkan keluhannya pada sistem LAPOR, sehingga pada pelayanan publik yang diterima oleh masyarakat di Desa Semanding semakin optimal dan memenuhi kebutuhan mereka. Kedua, mengoptimalkan jaringan internet yang ada di Kantor Desa Semanding agar masyarakat yang ingin menggunakan sistem LAPOR maupun kebutuhan akan akses informasi lain yang dapat menunjang perekonomian, kesehatan, dan pengetahuan penduduk di Desa Semanding dapat terpenuhi.

\section{DAFTAR PUSTAKA}

Alwi, Hasan. 2002. Kamus Besar Bahasa Indonesia Edisi Ketiga. Jakarta: Balai Pustaka.

BPS Kabupaten Tuban 2018.

Kecamatan Semanding dalam Angka 2018.

Soedjais, Zaenal dan Riant Nugroho Dwidjowijoto. 2002. Korporasi Pembangun Nilai: Tujuh Agenda Manajemen Korporasi. Jakarta: RBI Research.

Tjiptono, Fandy. 2009. Strategi Pemasaran, Edisi Kedua, Cetakan Ketujuh. Yogyakarta: Andi Offset.

www.lapor.go.id. 